\title{
Sustainable community development as an integral part of sectoral plans in South Africa
}

\author{
B. van Schalkwyk, C. Schoeman \& J. Cilliers \\ School van Geo and Spatial Sciences, \\ North-West University Potchefstroom, South Africa
}

\begin{abstract}
Sustainable community development is needed in order to create more integrated and sustainably developed towns and cities with an improved urban environment and to ensure higher quality of life. Such a development approach is therefore of particular relevance to South Africa. Although policies and legislation regarding sustainable development exists at international, national and local level, there is a lack of planning instruments to guide sustainable community development.

In this paper Tlokwe Local Municipality is researched as study area to test and develop planning instruments for sustainable community development. A Goal Assessment Matrix (GAM) approach is applied to score and prioritise municipal projects, plans and strategies according to sustainable community development fundamentals. The top scoring projects are indicative of the achievement of sustainable community development goals and objectives. Subsequent to the GAM assessment a lack of alignment between the sectoral plans was identified as well as the duplication of projects. The projects, plans and strategies of the municipality are not formulated and integrated with the sustainable community development framework as a guiding goal or main focus.

An approach is developed for municipalities to apply the assessment matrix methodology to determine its level of sustainability when formulating its sectoral plans (Spatial Development Frameworks, Integrated Transport Plans, Environmental Management Frameworks and Integrated Development Plans). Areas in which there is a lack of sustainability are highlighted and can consequently be addressed through intervention strategies. Prioritising municipal projects, plans and strategies through the application of the GAM methodology enables municipalities to identify crucial projects that need special attention to ensure its successful implementation. This will largely assist and promote
\end{abstract}


sustainable community development. This paper illustrates that the GAM approach is a valuable planning instrument with which to achieve and support sustainable community development.

Keywords: sustainable community development, sectoral plans, goal achievement matrix.

\section{Introduction}

Under the Apartheid regime South African cities have developed in a distorted, fragmented and uneven manner. This development included unequal distributions of resources, power, democracy and freedom of movement to the city inhabitants [1]. The Apartheid legacy in South Africa has only made the usual problems associated with urbanisation, such as housing and service delivery, more complex.

With the release of the Brundtland Commission's report in 1987 the concept of sustainable development became a well-established and recognised concept worldwide. It became common knowledge that without protection of the environment, development will not be sustained, but also that sustainable development cannot happen if certain social and economic factors don't support it. It was only logical that the two terms of community development and sustainable development should merge into a new concept: sustainable community development.

The legacy of apartheid left in its wake divided cities, townships with minimal facilities and services, low-cost areas with rows of standardised houses, rampant urban sprawl, high transportation and environmental costs, widespread poverty and high levels of unemployment. Fittingly the South African government is taking measures to address the abovementioned challenges. Development principles for sustainability have been adopted at national, provincial and local government level (municipal) in Agenda 21, the National Framework for Sustainable Development (NFSD) and Municipal bylaws. These form the basis for sustainable community planning and development. A sustainable community is a community that is economically, environmentally and socially healthy and resilient. Sustainable community development is necessary in order to achieve more integrated and sustainable towns and cities with an improved urban environment and a higher quality of life.

It is the aim of this paper to illustrate how the Goal Achievement Matrix (GAM) method can be used to identify priority community development projects in sectoral plans for implementation by local municipalities. For the purpose of this paper the Tlokwe Local Municipality (TLM) was used a study area for the implementation of the GAM assessment.

\section{Fundamental elements of sustainable community development}

The definition of sustainable community development is similar to the definition of sustainable development, the foremost difference involving spatial scope and 
focus. Where sustainable development is a global concept, sustainable community development is local. Bridger and Luloff [2] state that the "definitions of sustainable community development stress the importance of striking a balance between environmental concerns and development objectives while simultaneously enhancing local social relationships”.

The Institute for Sustainable Communities (ISC) [3] describes a sustainable community as one that is economically, environmentally and socially healthy and resilient. The ISC [3] further states that a sustainable community "meets challenges through integrated solutions rather than through fragmented approaches that meet one of those goals at the expense of the others".

Sustainable communities comprise different fundamental functional elements. These elements are incorporated and reflected in the planning proposals and urban development pattern. The Nelson Mandela Bay Municipality [4] argues that there are six main functional elements as illustrated in fig 1.

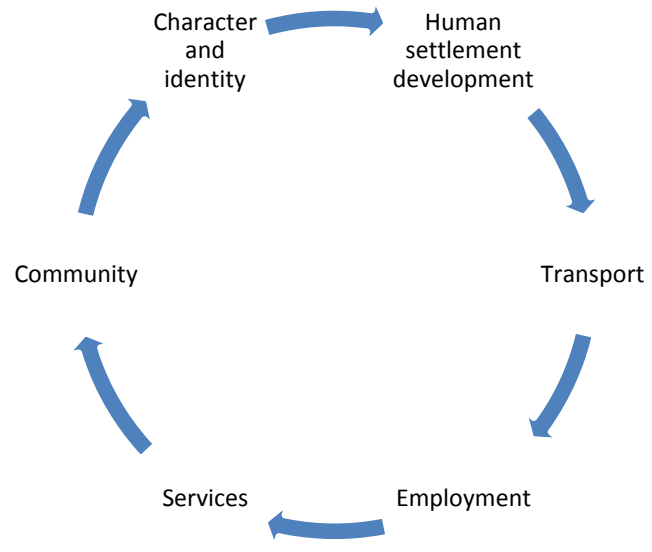

Figure 1: $\quad$ Fundamental functional elements of a sustainable community.

These elements can be described accordingly.

Human settlement development:

The quality of the urban living environment is determined by the character and quality of housing. Housing meets a basic need, provides a family with living context and represents values and aspirations. The Breaking New Ground Plan by the Department of Human Settlements [5], which originated from the UN HABITAT report, calls for a shift away from product uniformity to demand responsiveness. They argue that there should be moved away from the norm of "single houses on single plots in distant locations". Diversity in the types of housing promotes socio-economic, cultural and ethnic integration.

Transport:

Transport systems include different modes of transport for private and public transport and for the transportation of goods. The different modes of 
transportation in a transport systems should complement each other and be linked in an overall structure [6]. In a sustainable community transport needs to be manifested in an integrated system with an emphasis on pedestrians, bicycles and public transport. The spatial structure of a community is defined by transport routes. To achieve integration and sustainability, the correct provision of transport is essential [7].

\section{Employment:}

Dewar and Todeschini [8] state that the most common form of settlementmaking in South Africa is quantitatively driven and consists of achieving a balance between the area of the land parcel and the demands made upon it. This approach contains inherent problems, including the fact that it results in an environment that is inefficient and non-generative for income generation. In sustainable communities local economic development (LED) should be supported in spatial and functional terms. Economic and social integration and sustainability is enhanced by opportunities that promote local work, trading, income generation and circulation of money. Employment is the primary means of obtaining income, and is thus the key to economic sustainability.

\section{Services:}

Quality of life within a community is measured by the availability, access and quality of services. There are certain essential services that a community needs in order to function properly. Good quality services address disparities in service levels which in turn promote mixed income levels and results in social integration. Physically integrating services and sharing facilities contribute to financial sustainability and reduces the need to travel.

\section{Community:}

The term community refers to how people live together, interact and co-operate. Community development, positive social interaction and local organisation are fundamental to the development of a sustainable community. Sustainable communities are characterised by their community spirit and a sense of togetherness and this ensures their continued development. If people have a sense of safety, serenity, belonging, harmony and high quality community life they feel they belong in the area and wish to remain and contribute to the community's development over time. Residents are able to raise issues and problems and seek solutions together through community organisations and local informal and organised structures [4].

Character and identity:

The culture and lifestyle of the inhabitants of a community determine the character and identity of that community. The quality of the built and natural environment also influences the character of the community and contributes to social identity and sustainability. Townscapes and surroundings should be functional and well designed as they foster positive and responsible attitudes in residents. 


\section{Sustainable community development in South Africa}

Communities of the developed world are faced with different challenges than the developing world in achieving sustainability. Roseland [9] argues that the elementary problem with developed cities is that they are unsustainable while developing cities face the challenge of being underdeveloped. While most residents of developed cities are adequately housed and fed, they meet their needs by consuming at rates that are not sustainable. In contrast many developing city-dwellers cannot even meet their basic needs. Though this contrast is not absolute, it assists in illustrating the difference in challenges of urban sustainability by both developing and developed countries. This is especially true in South Africa where policy makers have to contend not just with environmental factors, but also with the social injustices inherited from Apartheid. A community cannot be truly sustainable until all spheres of sustainability (economical, environmental and social) are addressed.

Communities and cities in South Africa were originally spatially designed around Apartheid principles that focussed on keeping race groups separate with preferential access to economic opportunities for whites [10]. Despite the best intentions of the government since 1994 to undo these impacts and to integrate settlements along social and racial lines, the legacy of apartheid remains.

During its peak of international popularity, community development was not popular in South Africa largely due to the scepticism and mistrust the government had, owing to its potential for political change. Later on the government made an official study of community development and found that it would be beneficial to implement such projects and effort, though these were undertaken on a rather small scale [11]. Community development in South Africa was mostly carried out in an isolated, fragmented manner, on a small scale, and most often by NGOs. Later on the responsibility of community development passed onto many government departments and currently resides with the Department of Human Settlements and the National Planning Commission.

South Africa had various strategies and programmes that included sustainable development initiatives, but there was no overarching, all-inclusive national strategy or policy for sustainable development. The National Framework for Sustainable Development of 2008 was created to address this void. The NFSD gave a broad framework for sustainable development that served as a basis for developing national strategies and action plans [12]. The NFSD's purpose was to give direction to the national vision for sustainable development and to highlight interventions to re-orientate South Africa's development path. The NFSD did not provide detailed strategies and actions for sustainable development, but rather "proposes a national vision, principles, trends, strategic priority areas and a set of implementation measures" [12].

The Department of Human Settlements released "Breaking New Ground" (BNG) in 2004 as a comprehensive plan for the development of sustainable human settlements. The challenges that were highlighted in the BNG plan focused on housing backlogs and poor service delivery while very little mention 
was made of environmental and social factors when discussing the development of sustainable human settlements. Despite this it listed expedient plans for housing delivery which could aid in the development of sustainable communities.

In 2011 the National Development Plan was released providing guiding objectives to eliminate poverty and sharply reduce inequality by 2030 [13] Several sections of the National Development Plan pertained directly to sustainable community development, for instance improving infrastructure which called for upgrading informal settlements or reversing the spatial effects of apartheid [13], while all sections as a whole would contribute to sustainability in the long term.

\section{Sectoral plans in South Africa}

The Integrated Development Plan (IDP) is the main strategic instrument which guides all planning, investment, development and implementation decisions across sectors and spheres of government. The Department of Rural Development and Land Reform [14] states that the IDP is the overall strategic development plan that guides decision making, budgeting and development within a municipality. The Tlokwe City Council [15] further states that the IDP is a cross departmental instrument linking physical, social, institutional and economic components of planning with the management and development structure. The IDP provides an opportunity for municipalities and communities to deliberate and interact on issues of local development [16]. This interaction forms part of the public participation process for the formulation on an IDP and is crucial for the implementation of sustainable community development. Different levels of IDPs exist. The National Development Plan gives guidance to the Provincial IDP which in turn acts directs the IDPs of district municipalities. Local IDPs are the lowest order IDP and gives direction to local development.

The IDP for the TLM gives the situation analysis of the municipality [15]. This analysis includes basic demographics figures, such as income, and basic facts and figures which include socio-economic data. The opportunities offered by the TLM are also listed in the IDP [15]. This identifies areas of growth potential within the TLM. These areas of opportunity can be harnessed to improve the overall development of the TLM and positively impact on sustainable community development. The directive principles of the spatial rational for the IDP include equality, efficiency, integration, sustainability and fair and good governance [15]. These are all principles needed for the successful implementation of sustainable development and more specifically sustainable community development and planning.

In the IDP [15] intervention areas for basic service delivery are highlighted. These areas for intervention were identified through community participation processes. Action plans and opportunities for LED are also identified in the IDP [15]. Both public participation and LED is needed to create sustainable communities as these are both fundamentals of sustainable community development. 
The Spatial Development Framework (SDF) is a critical and integral component of the IDP because it shows "how the implementation of the IDP should occur in space" [14]. The Masilonyana Local Municipality [17] states that a SDF is one of the many components on an IDP and that it is in essence "the picture of the IDP”, illustrating the form and extent of development that the municipality wishes to promote. A SDF consists of an explanatory report and graphical representation (in the form of maps) of the desired spatial form of the Province or Municipality [18]. The Department of Rural Development and Land Reform [14] state that the formulation on a SDF is a legal requirement for all municipalities and provinces.

According to the North West Province [18] spatial planning, development and land use management ought to be guided by a "hierarchy" of SDFs. A SDF should include the following indications:

- $\quad$ Areas for public and private development and infrastructure investment

- $\quad$ Environmentally sensitive areas

- Areas of pollution concentration

- $\quad$ Areas where development or certain land-uses should be restricted

- $\quad$ Areas where priority expenditure should take place

- $\quad$ Guidelines for development and land use decision-making [18]

These elements of a SDF are all fundamental to the realisation of sustainability as they address the sustainability pillars of people, planet and profit. The ultimate goal of the SDF is to achieve the desired spatial form of the municipality as based on the vision for the development of the area and available resources [14].

According to the Tlokwe City Council [15] the SDF of Tlokwe "summarises key LED projects as well as areas for capital project investment in terms of the settlement hierarchy” as laid out by the North West Provincial SDF. The SDF of Tlokwe gives a thorough analysis of the study area [19] which includes an administrative, demographic, economic, land use and environmental analysis. The SDF of Tlokwe provides the basic structure from which to implement sustainable community planning and development as it is an illustration of the form and development the TLM wishes to promote.

The role of sectoral plans is to provide a basis for detailed sustainable community planning and sustainable community planning initiatives. The planning framework of sustainable community development is closely related to the principles of the IDP and the SDF. The different levels of spatial planning should be inter-linked and connected to the financial planning as well as to the implementation programmes as shown in fig 2. These levels of spatial planning for sustainable community development should be reflected in the IDP and its supporting sectoral plans.

\section{GAM application}

A Goal Achievement Matrix assists with the assessment and prioritization of projects and programmes [20]. According to the Department of Transport [20] 


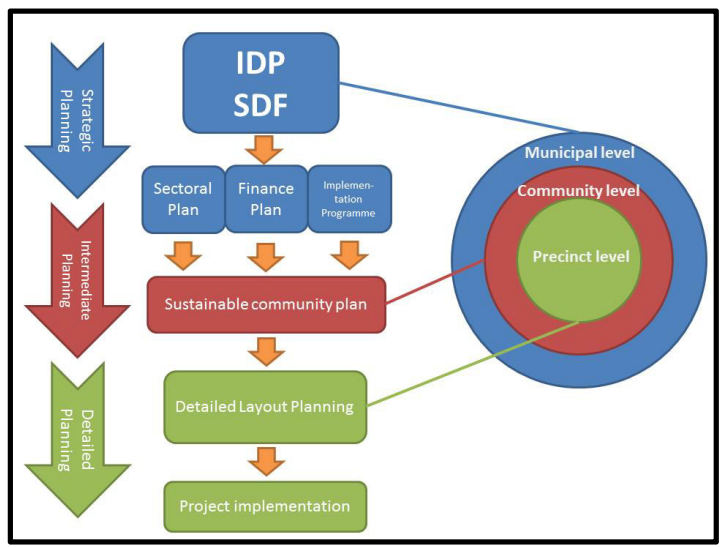

Figure 2: $\quad$ Application of the planning framework for sustainability.

"to identify, assess and prioritise projects; specific policy, goals and objectives are firstly required with the aim of measuring individual projects against them”. Hill [21] states that the goal used in the GAM is "an end to which a planned course of action is directed". These goals should be defined operationally as to be expressed as objectives. Hill [21] says that "in this way the degree of achievement of the various objectives can be measured from the costs and benefits that have been identified".

In order to prioritise projects and programmes for sustainable community development as contained in the IDP and sectoral plans (SDF, EMF and ITP) of a municipality the GAM approach is used. Table 1 illustrates the GAM based on the fundamental elements of sustainable community development. The fundamental elements were derived from the functional elements of sustainable communities as mentioned earlier.

Each project identified in the sectoral plans should be adjudicated in terms of how well it contributes to the set of sustainable community development fundamentals in Table 1 . The total sum of its contribution is referred to as the GAM score and ranked from highest to lowest based on this score. Projects should be implemented from the highest to the lowest score with the top six highest ranked projects to be considered crucial for the creation of sustainable communities. These crucial projects should receive the highest level of effort to ensure their implementation. Any project scoring below 16 will not be considered a crucial project since it achieved a score of less than $50 \%$ (out of a possible 30).

The GAM evaluation method is proposed to be used to identify priority sustainable community development projects for implementation by the TLM. The SDF, EMF, ITP and IDP all list projects which have been identified based on need and desirability. The implementation period and estimated cost listed include all phases of the project from plan formulation, application for funding to project execution. 
Table 1: Goal Achievement Matrix (GAM) for IDP and sectoral plan evaluation.

\begin{tabular}{|c|c|c|c|}
\hline \multirow{2}{*}{$\begin{array}{l}\text { Sustainable } \\
\text { Community } \\
\text { Development } \\
\text { Fundamental }\end{array}$} & \multicolumn{3}{|c|}{ Score/Weight } \\
\hline & 1 & 3 & 5 \\
\hline $\begin{array}{l}\text { 1. Creating an } \\
\text { integrated and } \\
\text { sustainable human } \\
\text { settlement system }\end{array}$ & $\begin{array}{l}\text { Maintaining the } \\
\text { status quo. }\end{array}$ & $\begin{array}{l}\text { Provide adequate } \\
\text { housing and } \\
\text { amenities. }\end{array}$ & $\begin{array}{l}\text { Contribute largely to } \\
\text { a quality urban living } \\
\text { environment through } \\
\text { quality housing. }\end{array}$ \\
\hline $\begin{array}{l}\text { 2. Supporting LED } \\
\text { development and } \\
\text { delivery }\end{array}$ & $\begin{array}{l}\text { Maintaining the } \\
\text { status quo. }\end{array}$ & $\begin{array}{l}\text { Provide some } \\
\text { economic and } \\
\text { spatial } \\
\text { development } \\
\text { opportunities. }\end{array}$ & $\begin{array}{l}\text { Contribute largely to } \\
\text { the facilitation of } \\
\text { economic activities } \\
\text { and spatial } \\
\text { opportunities. }\end{array}$ \\
\hline $\begin{array}{l}\text { 3. Provide good } \\
\text { quality services, } \\
\text { both bulk and } \\
\text { internal }\end{array}$ & $\begin{array}{l}\text { Maintaining the } \\
\text { status quo. }\end{array}$ & $\begin{array}{l}\text { Provide a limited } \\
\text { improvement in } \\
\text { the availability and } \\
\text { quality of services. }\end{array}$ & $\begin{array}{l}\text { Contribute largely to } \\
\text { relieving the need for } \\
\text { bulk services and } \\
\text { improve the quality } \\
\text { and accessibility of } \\
\text { internal services. }\end{array}$ \\
\hline $\begin{array}{l}\text { 4. Contribute to an } \\
\text { effective public and } \\
\text { private transport } \\
\text { system }\end{array}$ & $\begin{array}{l}\text { Maintaining the } \\
\text { status quo. }\end{array}$ & $\begin{array}{l}\text { Provide a limited } \\
\text { improvement in } \\
\text { transport linkages } \\
\text { and accessibility. }\end{array}$ & $\begin{array}{l}\text { Contribute largely to } \\
\text { the improvement of } \\
\text { linkages and } \\
\text { accessibility of } \\
\text { transport. }\end{array}$ \\
\hline $\begin{array}{l}\text { 5. Foster an } \\
\text { inclusive } \\
\text { community spirit } \\
\text { and a sense of } \\
\text { togetherness }\end{array}$ & $\begin{array}{l}\text { Maintaining the } \\
\text { status quo. }\end{array}$ & $\begin{array}{l}\text { Provide some } \\
\text { improvement to } \\
\text { community spirit } \\
\text { and sense of } \\
\text { togetherness. }\end{array}$ & $\begin{array}{l}\text { Contribute largely to } \\
\text { community } \\
\text { development, positive } \\
\text { social interaction and } \\
\text { diversification. }\end{array}$ \\
\hline $\begin{array}{l}\text { 6. Contribute to a } \\
\text { community } \\
\text { character of } \\
\text { accountability and } \\
\text { social identity }\end{array}$ & $\begin{array}{l}\text { Maintaining the } \\
\text { status quo. }\end{array}$ & $\begin{array}{l}\text { Provide some } \\
\text { improvement to } \\
\text { character and } \\
\text { social identity in } \\
\text { the community. }\end{array}$ & $\begin{array}{l}\text { Contribute largely to } \\
\text { fostering positive and } \\
\text { responsible attitudes } \\
\text { in residents. }\end{array}$ \\
\hline
\end{tabular}

Each project within the sectoral plans is scored using the GAM given in Table 1 in accordance with the sustainable community development fundamentals and prioritized according to the total GAM score. The scoring of projects enables the TLM (or other local municipalities) to easily identify the priority projects associated with each sectoral plan. The top six GAM scores are used to identify the crucial priority projects from all four sectoral plans to be implemented.

It is advised that the identified projects should be implemented from the highest score to the lowest score in the financial year allotted as the implementation period for the project. Projects scoring 22 or more are considered vital and should receive the highest level of effort to ensure their successful implementation. 
Upon examination and GAM assessment of the sectoral strategies and projects of the TLM, certain gaps and errors were identified:

- A pertinent lack of alignment between the sectoral plans is perceived in the duplication of projects. It appears as if each sectoral plan was drafted in isolation without inputs from other departments or stakeholders.

- $\quad$ No project or strategy attained a score higher than 26 out of a possible 30, indicating that the objective of sustainable community development wasn't taken into consideration during the formation of the sectoral plans.

- Certain aspects of sustainable community development (nodal development, densification, urban integration, urban quality, precinct planning and regeneration) are poorly addressed or omitted entirely from the plans, projects and strategies.

\section{Conclusions and recommendations}

The IDP and its supporting sectoral plans are crucial instruments in the achievement of sustainable development and sustainable community development as they direct expenditure and development within a municipality. Sectoral plans provide an opportunity for public participation which enables a community to give their opinion on how development should be implemented. The compilation process of sectoral plans also allows for interaction between municipalities and departments to deliberate on issues of local development.

A local authority can apply planning instruments such as the GAM approach to prioritise projects and strategies. It is to a municipality's own advantage to assess and prioritise the projects and strategies contained in their sectoral plans as this indicates which projects will contribute the most to achieving goals set forth by the municipality. For the purpose of this paper the goal was sustainable community development and a GAM was created according to this objective (Table 1). Since every sphere of government's, and every area's, view and objectives regarding sustainability and sustainable community development isn't identical a local municipality can transform the GAM to custom fit the unique challenges of the area. It was determined by the application of a GAM on the case study (TLM) that the projects set forth by the various sectoral plans are unaligned and appear to have been devised in seclusion from other sectors and departments.

Sustainable development is currently an objective of the IDP and other sector plans (SDF, EMF, ITP). While this is the ideal, the reality often falls short of the dream. Through the application of a GAM it was deduced that not all plans and strategies contained in the IDP are formulated to result in sustainability. The current statutory planning approach is based on need and desirability. Town planning concerns the what, where and when of development and if desirability and need are the only guiding factors in decision making and project formulation in the IDP and supporting sectoral plans sustainability will never be achieved. While current statutory planning approaches are based on need and desirability it is imperative that sustainability also be incorporated into the decision making process, as is illustrated in fig 3. 


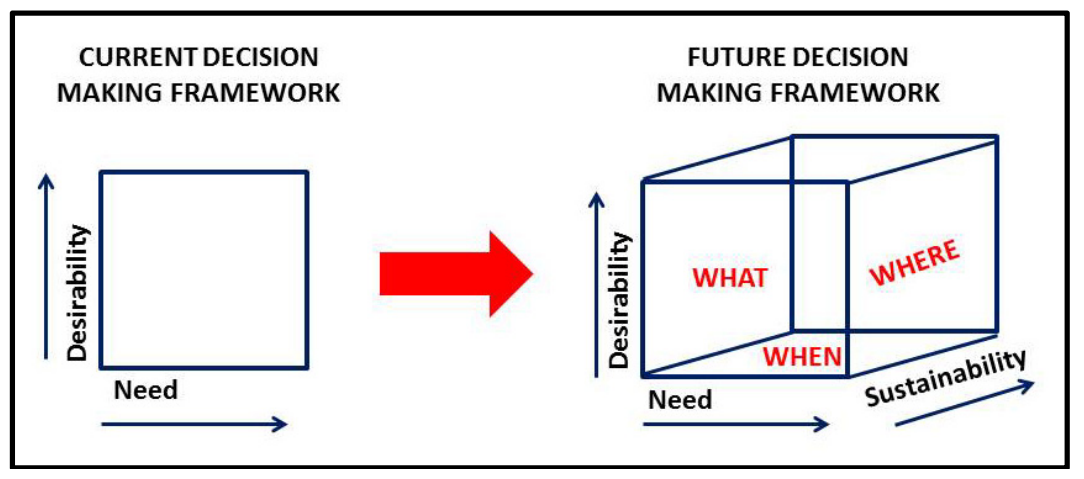

Figure 3: Decision-making frameworks.

The use of GAM can assist the prioritisation of sectoral plans' projects and strategies and enhance sustainable community development. It is recommended that a GAM assessment of all sectoral plans should be conducted as part of the revision and compiling phase to ensure the alignment of objectives, plans, projects and strategies toward the predetermined goal of sustainable community development.

\section{Acknowledgements}

This research was made possible by the financial contribution of the NRF (National Research Foundation) South Africa. Any opinion, findings and conclusions or recommendations expressed in this material are those of the author(s) and therefore the NRF does not accept any liability in regard thereto.

\section{References}

[1] Collins, J. Urbanisation. http://www.bcb.uwc.ac.za/envfacts/facts/ urbanisation.htm Date of access: 24 October 2011, 2001.

[2] Bridger, J.C. and Luloff, A.E. Toward an international approach to sustainable community development. Journal of Rural Studies, 15, 1999.

[3] Institute for Sustainable Communities. What is a sustainable community? http://www.iscvt.org/what_we_do/sustainable_community/ Date of access: 10 Sept 2012, 2012.

[4] South Africa. Nelson Mandela Bay Metropolitan Municipality. Integrated Development Plan, 2006.

[5] South Africa. Department of Human Settlements. Breaking new ground: A comprehensive plan for the development of sustainable human settlements, 2004.

[6] CSIR. Guidelines for Human Settlement Planning and Design. Pretoria: Capture Press, 2005.

[7] Selman, P. 1996. Local Sustainability: Managing and Planning Ecologically Sound Places, London: Paul Chapman Publishing Ltd. 
[8] Dewar, D and Todeschini, F. Urban management and economic integration in South Africa. Cape Town: Francolin Publishers Ltd, 1999.

[9] Roseland, M. Sustainable community development: integrating environmental, economic, and social objectives. Progress in Planning, 54, 2000.

[10] South African Cities Network. Creating sustainable communities: a history. http://www.sacities.net/knowledge/studies/history Date of access: 06 February 2012, 2011.

[11] De Beer, F. and Swanepoel, H. Community development and beyond. Pretoria: J.L. van Schaik Publishers, 1998.

[12] South Africa. Department of Environmental Affairs and Tourism. A National Framework for Sustainable Development in South Africa, 2008.

[13] South Africa. National Planning Commission. National Development Plan: Vision for 2030, 2011.

[14] South Africa. Department of Rural Development and Land Reform. Guidelines for the formulation of Spatial Development Frameworks, 2010.

[15] Tlkowe City Council. Tlokwe City Council Draft IDP review 20092010. http://www.docstoc.com/docs/73010240/TLOKWE-CITYCOUNCIL. Date of access: 25 Oct 2012, 2009.

[16] Tshabalala, E.L. and Lombard, A. Community participation in the integrated development plan: a case study of Govan Mbeki Municipality. Journal of Public Administration, 44(2), Jun, 2009.

[17] Masilonyana Local Municipality. Spatial Development Framework: Phase 1, 2010.

[18] South Africa. North West Province. North West Land Use Management Bill: Land Use Policy Framework Report 2, 2008.

[19] Tlokwe Local Municipality. Tlokwe Spatial Development Framework 2008, 2008.

[20] South Africa. Department of Transport. National Transport Master PlanPhase 4: Agenda for action, 2010.

[21] Hill, M. A Goal-Achievement Matrix for evaluation alternative plans. Journal of the American Institute of Planners, 34(1):19-29, 2007. 